\title{
EU Equality Commitments and Shifting Meanings of Gender
}

\section{Equality}

\author{
Erin J. Black
}

\begin{abstract}
This article follows the development of a European Union gender equality regime through three broad periods: equal treatment policies, positive action measures, and Gender Mainstreaming. The policy-making process entails conflict between competing policy frames; unequal resources behind each secures the dominance of an economic frame. Strategical framing practices have been employed by equality advocates to overcome this disadvantage. This article traces the gradual shifts in meaning within each period until equality goals are integrated into the dominant economic policy frame. It concludes that equality advocates need to engage in deeper analyses of power in order to sustain attention to equality goals over longer periods of time.
\end{abstract}




\section{Introduction}

The European Union (EU) has held commitments to gender equality since the Treaty of Rome in 1957. Gender equality is a central commitment of the EU and has expanded into the most far-reaching gender regime of any regional organization worldwide. It is essential to examine the way in which this regime has developed and the broader context where the meanings of gender equality have been negotiated. Economic growth, which has always been a fundamental objective and focus of the EU, has been the dominant policy frame and has shaped understandings and representations of gender equality concepts within legislation. The consequence of considering gender equality from an economic frame has been the gradual subordination of equality concepts and their eventual co-optation of meaning in support of the pursuit of employment targets and economic growth, rather than equality between women and men. Approaches to gender equality adopted by the EU can be grouped into three broad time periods: equal treatment measures which were adopted during the 1970s; positive action measures which were largely used in the 1980s and 1990s; and Gender Mainstreaming (GM) which was introduced in the 1990s. These approaches were initially modeled on feminist understandings of equality, but during each period there was a gradual shift back towards economic concerns. A historical perspective reveals that the EU has maintained a liberal approach to equality as 'sameness' and has promoted female participation in the labour market as the most suitable way to achieve both equality and employment targets simultaneously.

Feminists have often created connections between competing policy goals such as equality and economic growth in order to find a resonance between them. This resonance increases the likelihood that equality goals will be incorporated into the dominant policy agenda. This act of creating linkages is known as strategical framing and has been employed by feminists in each of the three time periods. Strategical framing has been effective in creating space for equality concepts, but over time there has been a gradual shift away from the original meaning of the concepts and they have been infused with alternative meanings which support other priorities. Such shifts in meaning have occurred incrementally and unevenly. This has resulted in the coexistence of policies which reflect conflicting notions of gender equality, and in some cases the coexistence of conflicting meanings within one policy document. When EU equality 
legislation is examined from a broader historical perspective it becomes evident that over time dominant policy frames have absorbed equality concepts so that equality goals become secondary issues of concern and are used to legitimate a focus on employment targets and economic growth. While strategical framing can be a very powerful and useful strategy to help stimulate the adoption of new goals onto the EU policy agenda, it must be done carefully as it increases the risk of full co-optation of the initial meaning.

I will begin by looking at policy frames and examine the policy-making process using a frame analysis. Given that there are numerous interpretations of any policy issue and various ideas of how issues should be prioritized, the policy creation process is a struggle over domination and subordination, which determines how issues will ultimately be given priority on the policy agenda. I will then examine how EU gender policy has developed within each of the three defined periods, with attention to women's activism and organization and the impact this has had upon policy development, the extent to which strategical framing was employed, and gradual shifts in the meaning of equality concepts. This historical analysis reveals that, despite the extensive gender regime of the EU, equality legislation has faced numerous challenges which continue with current practices of GM. GM is a promising policy approach which has significant potential to be transformative of the dominant order, but faces inherent dangers of co-optation and so far has merely been integrated into dominant policy frames. In order for GM to retain coherence as an innovative policy which can achieve equality between women and men, it must retain the ability to challenge dominant norms. Strategical framing, while sometimes advantageous when used with other approaches to equality, is detrimental when employed within a strategy of mainstreaming as it reshapes GM within an integrationist approach instead of striving for its transformative potential. Strategical framing practices require a deeper analysis in order to understand how power functions between two competing policy frames. Further development of equality policy within the EU demands greater attention from both policymakers and feminists to ensure that equality legislation retains coherence and effectiveness at bringing us closer to a society free from the inequalities of gender. 


\section{Approaches to Gender Equality}

The effect of political discourses and policies upon individual citizens and relationships is mediated by gender. State policies constrain gender roles and shape notions about both the differences, and similarities, between men and women. Even policies that claim not to focus on gender have gendered consequences for men and women. The traditional policy frame of the EU was one of economic growth and gender concerns were generally disregarded in the design of state family and welfare policies; yet, such policies were founded upon the traditional division of labour and the male breadwinner family form, with a dependent wife and a working husband (Mazey 1998: 135). State policy is an important terrain within which to employ a gender critique as it has significant implications for how individuals organize their private lives.

Feminists have not come to any general consensus on a theory of the state and debates within feminist literature continue to this day about where the problem of gender inequality lies and what the solution is. The vision of a society free from the inequalities of gender has been conceptualized in at least three different ways, all of which translate into different political strategies. Gender equality can be seen as 'sameness,' 'difference,' or the transformation of all established norms and standards related to gender and what it means. These have been articulated as the strategies of 'inclusion,' 'reversal,' and 'displacement' (Squires 2005: 367). Those pursuing a strategy of inclusion wish to extend dominant values to men and women equally, aspire to objectivity, conceive of people as autonomous and the state as neutral, and are often defined as liberal feminists. The strategy of reversal takes up a politics of difference, seeks recognition of a distinctive female identity, and views the state as patriarchal and thus has a key role in perpetuating gender inequalities; those pursuing this strategy are often labeled radical feminists. The strategy of displacement aims to move beyond gender by deconstructing those discursive regimes which actively engender the subject; this is most often defined as a postmodern perspective (Squires 2005: 368). These are conceptualized as an 'equal treatment' policy frame, a 'woman's perspective' frame, and most recently a 'gender' policy frame, respectively. All three approaches to gender equality have been employed by the EU and can be situated within fairly distinct time periods of the EU's history.

The introduction of equal opportunities legislation as a concern for the EU stemmed from Article 119 of the 1957 Treaty of Rome, which referred explicitly to the right of women to equal 
pay with men in the labour market. This Article has been the cornerstone for all subsequent EU social policy. Inclusion of Article 119 was precipitated by the French government, which had expressed concern that its highly paid female labour force would be undercut by lower wages from elsewhere (Duncan 2002: 306). It was intended to create fair and equal competition between member-states by preventing any one state from gaining a competitive advantage by paying women at lower wages. Thus, gender equality initially became an area of concern to the EU through a frame of competition and economic growth, rather than through one of equality and social justice. Thus, from its very inception within the Treaty of Rome, gender equality was tied to employment and labour market concerns. This constitutionally limited the social dimension of the EU to labour market creation, and subsequent social policy expansion was compelled to find its justification from within employment arguments (Young 2000: 84). In the early years of the European Economic Community (EEC), interest in equality between men and women coincided with second-wave feminism, and gradually Community institutions extended their purview to address some of the various aspects of women's economic activity.

Teresa Rees outlines three phases of the European Commission's (EC) approach to gender equality over the last three decades: equal treatment in the 1970s, positive action in the 1980s, and GM in the 1990s. Equal Treatment measures are primarily concerned with the inclusion of women into already-existing structures and norms and is largely a "legal redress" to treat men and women the same. Positive action recognizes differences between men and women and maintains that specific actions are necessary in order to assist women in a overcoming their disadvantage in a patriarchal society. GM involves the incorporation of gender issues into all policies and institutions. GM identifies how institutions and structures implicitly and perhaps unwittingly reinforce gender disadvantages and maintain male patriarchy. It then redesigns these structures and institutions appropriately in order to transform the policy process in a way that is not gendered (Squires 2005: 370). These three approaches are generally viewed to be complementary, cumulatively building upon each other and have emerged progressively within the EU over time. She labels these approaches 'tinkering,' 'tailoring,' and 'transforming,' in terms of their relationship to dominant norms (Rees 1998: 48). The development of EU gender policy has paralleled the development of feminism in its various strands (liberal, radical, and post-structural feminism). This is largely due to the fact that the EU is a relatively young institution and has allowed groups multiple points of access within EU political structures. 
Various gender equality offices have been inserted into the European institutional machinery and have forged strong networks with independently organized women's groups. This velvet triangle has been active within all periods of EU gender policy and has encouraged the placement of equality goals on the EU policy agenda but has still been met with resistance from policy actors. Conflicting policy frames have restricted the scope of equality goals, leading feminists to employ different strategies to further increase the likelihood of placing equality goals on the policy agenda.

\section{Policy Frames and Strategical Framing}

Carol Lee Bacchi has argued that inherent meaning does not pre-exist a policy issue or problem; rather, meaning is constituted within a broader context or frame of understanding (Bacchi 1999: 9). Rein and Schon define policy framing as "a way of selecting, organizing, interpreting and making sense of a complex reality in order to provide guideposts for knowing, analyzing and acting” (Rein and Schon 1991: 263). In other words, a policy frame provides a perspective from which an issue can be interpreted in order to determine how to respond or interact, which originates in underlying structures of belief. State policies are grounded within a particular policy frame. For instance, gender inequality in politics can be depicted as "women trailing behind men," in which case the solution would target women's behaviour, or it can be depicted as "men dominating positions of authority and excluding women," in which case the solution would target the issue of men's domination. The language or discourse of the policymaking process is important in defining and representing the policy issue at hand. Carol Lee Bacchi argues that every policy proposal contains an implicit or explicit diagnosis of what the 'problem' is, which she calls “problem representation” (Bacchi 1999: 1). The problem representation of a policy proposal defines the problem and creates the solution, impacting both the subject and the object of the resultant policy.

Frame analysis is concerned with identifying dominant and subordinate policy representations with a focus on language and discourse, as well as identification of the processes by which meanings are constructed in specific contexts (Peterson 2007: 266). Frame analysis starts with the assumption of numerous interpretations in the creation of policy and examines 
issues of dominance and subordination as they are made manifest. This creates space for a discussion of normative goals and increases awareness of the role that ideology plays in the creation of policy. The process of creating policy is a territory of struggle to determine which actor(s) will be involved in shaping the issues to be considered and to determine how they will be constructed or represented. This process is a conflict over competing policy frames and entails struggles over power. Resources allocated to each frame are likely to be unequal, making it more difficult for the subordinate frame to displace, or question, the dominant frame. Nancy Fraser notes that under conditions of inequality, deliberative processes are inclined to serve dominant processes and they fail to provide subordinated groups with an opportunity to articulate their voice or concerns (Fraser 1997: 81). In other words, subordinate frames are likely to be simply absorbed into the existing dominant frame. Maria Stratigaki has referred to this as the process of co-optation, which occurs when "the concept itself is not rejected, but its initial meaning is transformed and used in the policy discourse for a different purpose than the original one” (Stratigaki 2004: 36).

Strategical framing practices, which attempt to construct a "fit" or "resonance" between different frames to increase their chance of being incorporated into the policy agenda, increases the likelihood of co-optation of a concept's meaning. Strategical framing is based on the understanding that an inequality of power resources backing various frames impacts the likelihood of success. A dominant frame is more likely to incorporate another frame which is compatible, rather than in contradiction and conflict with it (Snow and Benford 1992: 137). This effectively provides a link between the two frames by stretching the meaning of the goal in order to secure the allegiance of those acting from within the dominant frame (Verloo 2005: 359). Feminists have often employed this strategy in order to facilitate the adoption of equality issues into the policy agenda. While this is certainly more effective in securing initial acceptance, there is an inherent danger in the strategy. The shape of ensuing power struggles are altered so that when the feminist goal is stretched, it is conceptualized as weaker than its original manifestation, and ultimately further potency is accorded to the dominant frame. This increases the likelihood for co-optation of the equality concept's original meaning as the dominant frame subsists and prevails, unchallenged in its various forms of inequality. Strategical framing of an equality goal can therefore be seen as a mix of enabling and constraining forces (Verloo 2005: 345). It provides an initial introduction onto the policy agenda which comes with additional mechanisms 
and increased opportunities to institute real change, but then the reshaping of equality goals to fit with the dominant frame results in a mere continuation of current understandings and practices. This has worked against the mobilization of feminists, as it has become more difficult to oppose new meanings of concepts which they originally championed (Stratigaki 2004: 36). While strategical framing was employed during each of the three periods identified in the EU's development of gender policy, it has been particularly within the most recent period of GM that it has been most detrimental to equality aims. The transformative potential of GM lies in its ability to challenge dominant norms and gendered processes; strategical framing practices weaken the conceptualization of GM and detract from its ability to address and redress gendered systems and processes. This weakens the transformative potential of GM and instead reshapes it into an integrationist approach, incorporating gender issues into existing policy frames rather than rethinking their fundamental aims. An analysis of all three periods of the EU's approach to gender equality further reveals representations of equality as understood through various policy frames, the strengths and limitations of strategical framing, and the extent to which there were shifts in the meaning of equality concepts.

\section{Equal Treatment Policies}

Liberal feminists view the role of the state, as it ought to be, as a neutral arbiter between conflicting interests and the guarantor of individual rights as promised by citizenship (Connell 1994: 141). They argue that the neutral state has been "captured" by men, and that redress is necessary in order to recover gender equality. Liberal feminists characterize the problem as men in command of governments, business, the military, and other institutions; as such, the solution is characterized as greater access for women to positions of authority in order to restore a more suitable balance (Connell 1994: 142). Liberal feminism emerged as a parallel discourse to European integration in the 1960s and 1970s, and both were critical in the adoption of EC measures ensuring women's equality in the labour market. The equality frame during this period can be identified as an 'equal treatment' policy frame.

The activities of liberal feminism during the late 1960s and early 1970s were catalytic to the increased attention to equality issues between women and men in the labour market. Feminist 
ideas and demands were a significant challenge to long-standing and traditional notions regarding the status of women. European feminists sought to reframe government policy which had significance for women, arguing that most importantly, there was a critical need to address discrimination in the labour market. Wage differentials between women and men were common throughout Europe, and equal pay for equal work became a central demand of women's protests. However, most national governments remained unreceptive to women's demands. When they were met with little response by national governments, feminists strategically turned to the EEC as a focus for their lobbying activities (Mazey 1998: 137). They invoked Article 119 in national equal pay campaigns, and it was Belgian women who were successful in placing the new gender equality policy frame on the European agenda - an equal pay strike in a munitions factory resulted in an increase to the wages of all female workers and garnered widespread publicity throughout Europe. Belgian lawyer Eliane Vogel-Polsky argued for a strong definition of Article 119 in the Defrenne case ${ }^{1}$ in front of the European Court of Justice (ECJ). This decision confirmed the direct applicability of Article 119 and extended it further, applying it to contracts between individuals and collective agreements (Hoskyns 1996: 93). While article 119 provided feminist groups with an entry point to support their demands for stronger gender equality legislation, other factors also made the EU more receptive to feminist demands. The EU was relatively unconstrained by pre-existing policies and a deeply entrenched policy frame given that it was a new political system, allowing easier adoption of the 'equal treatment' policy frame offered by women's groups. Women were strategic in targeting multiple access points to the policy process, and the EU was searching for new ways to extend its mandate in order to respond to recession and stagflation. Consequently, it cultivated strong connections with women's groups in order to legitimate its intervention in social policy areas. These connections were instrumental in placing gender equality on the European policy agenda in accordance with an 'equal treatment' perspective (Mazey 1998: 138). Feminist mobilization was met with relative receptiveness of the EU in light of the fact that extending gender policy would also extend EU jurisdiction.

\footnotetext{
${ }^{1}$ An air hostess had been forced to retire at age 40 from Belgian state airline Sabena, following company policy. She suffered loss of pay and pension entitlements, and had to search for work at a vulnerable age; this was further aggravated by company policy which gave any member of the air crew high pension entitlements which came close to full salary, except for air hostesses who received very little (Hoskyns 1996: 70).
} 
The introduction of a 1974 Council Resolution concerning a Social Action Program (SAP) authorized the EU to become involved with social issues and initiated a more active social policy engagement. The SAP included a section on equality between men and women in the labour market with the main emphasis being on increasing employment rates. Various women's groups were inserted into the EU political machinery, including the Women's Bureau, the European Women's Lobby (EWL), and the Women's Committee of the European Confederation of Trade Unions. These groups increased attention to equality issues and had considerable impact in the implementation of several equality measures. These measures addressed various aspects of equal treatment in the labour market. The 1975 Equal Pay Directive reaffirmed the principle of equal pay between men and women for work of equal value, the 1976 Equal Treatment Directive provided for equal treatment as regards access to employment, and the 1978 Directive concerned equal treatment in social security benefits. These were followed by a Directive in 1986 on equal treatment in occupational social security schemes, and another 1986 Directive on equal treatment in self-employment. Vocational training and employment schemes offered by the European Social Fund (ESF) aimed to promote equal opportunities for women in the labour market and in 1988, “equal opportunities between men and women” was adopted as a specific measure under Objective 3 of EU Structural policy (Stratigaki 2005: 170). The emphasis of these measures was on increasing women's access to the labour market rather than on a redistribution of opportunities, reflecting an 'equal treatment' policy frame which emanated from liberal feminists.

While feminists understood gender equality as equal treatment, there was an increasing sense that positive action was also necessary in order to achieve true gender equality. Jacqueline Nonon, an official in the Directorate General Employment and Social Affairs (DG V), had been given responsibility for preparing the equality Directives and she initiated an ad hoc working group on women's issues. The group believed that women needed equal treatment as well as positive action measures to achieve true gender equality; however, it was deemed more likely that the wider Community would adopt Directives focused on equality within the labour market. Indeed, the EC stated that it was concerned only with family policy insofar as it directly affected women's employment in the labour market (Hoskyns 1996: 102). As such, strategical framing was employed in order to create a "fit" with the economic frame of the EC, and the resultant 
Directives reflected this, addressing equality concerns of feminist groups (limiting the scope to an 'equal treatment' perspective) as well as economic concerns of the wider Community.

There were gradual shifts in the meaning of the equal treatment Directives and the ways they were implemented in various member states. Equal treatment Directives were used by various national governments to reduce social expenditures and encourage participation in the labour market, rather than being used to pursue positive integration through institutionalizing protective legislation for all employees in the labour market (Young 2000: 86). Legislation on supplementary benefits was revised to incorporate gender-neutral language, but effectively excluded access to many women who had domestic care giving responsibilities (Duncan 1996: 403). This illustrates some of the difficulties inherent in EU-level legislation - a multitude of political actors and arenas increases the likelihood that equality goals will be sidelined in the process of implementation. While they faced numerous difficulties upon implementation, application of these equality Directives was still undoubtedly of benefit to women in providing them with a legal redress for discrimination in the labour market. These "hard law" Directives are judicially enforceable and remain at the heart of EU interventions on gender inequality (Walby 2004: 7). Feminists were required to use strategical framing only to a moderate degree, as feminist ideas were resonant with the EU's dominant economic policy frame. An 'equal treatment' frame encouraged a focus on employment targets, and this focus continued within the EU’s shift towards positive action measures and work/life reconciliation policies.

\section{Work/Family Reconciliation Policies}

In comparison with liberal feminists who understand the state in terms of its political institutions, radical feminists extend their analysis to the broader structures of state and society. Radical feminism is not easy to define because it takes many forms. For the purposes of this paper, a rough sketch is sufficient although this is by no means a comprehensive account. Radical feminism is predicated on an understanding of intrinsic connections between the family, the labour market, and the state; inequalities reproduced in one sphere will be propagated within all three spheres. The state is viewed as "male" in that the social order is constituted in the interest of men and thereby reproduces gender inequalities, not only through legislation but also 
through social norms and regulation of the family structure (Mackinnon 1989: 162). The state's role in the oppression of women is often seen to be indirect - it regulates 'systems' such as the family and the labour market which reproduce inequalities of gender and are oppressive to women (Connell 1994: 144). The cultural distinction between public (masculine) and private (feminine) is problematized; the proposed solution, however, is not as evident. Some perceive this to be the end of the state itself given that it is predicated upon this distinction. Others argue in favour of state expansion, so that the state would effectively become broader and thinner and reshaped in the image of radical democratization of social interaction instead of favouring male privilege (Connell 1994: 165). Still others argue that the category "woman" has not been misdefined so much as it has been undervalued; they argue for a concept of equality that values caring responsibilities (Cain 1989: 836). From all accounts, the goal is to recreate reality from a woman-centred perspective. Whereas liberal feminists assume similarities between women and men, radical feminists tend to build their arguments around inherent differences between men and women, arguing that equal treatment is capable of only treating the symptoms of gender inequality but not the root causes; as such, politics must be reconstructed in order to recognize the distinctive perspective of non-hegemonic gender identities (Verloo 2005: 346). Given that radical feminists see patriarchy as embedded in state procedure, change must originate outside of the state in civil society, as actions within the state system will instinctively reinforce the patriarchal structure (Kantola 2006: 6).

The concept of the "double day" of paid and unpaid work suffered by women first appeared within feminist writing in the early 1970s as the number of women entering the labour market dramatically increased. This became an issue of concern for feminists as the need for non-parental child care strategies was compounded by increased participation in the labour market by women. Women's disproportionate share of care and domestic responsibilities came to be recognized as a direct cause of perpetuating gender inequalities in the family, as well as within the market and the state. As such, the pursuit of a gender equal society demanded a recognition for women's caregiving work as well as a redistribution of caring responsibilities to alleviate the double burden carried by women (Hoskyns 1996: 199). The concept of 'work and family reconciliation' was developed by feminists in order to highlight the connection between gender inequalities in the labour market and the home, and they demanded reconciliation policies which would provide caregiving services to allow women to move freely within the family and 
the labour market. Feminists lobbied for a need to reconceptualize care work to achieve an equal division of labour in the family, as well as the need for state policies to support unpaid care responsibilities. This discourse was embraced by the EU, and soon came to characterize the majority of EU equality policies during the 1980s and early 1990s. These policies were based on the feminist understanding that state provision of two types of care services can help alleviate these gender inequalities: first, non-parental childcare services help to alleviate women's care giving responsibilities and can facilitate participation in the labour market; second, parental leave policies allow a temporary absence from work, and can alternatively alleviate women's responsibilities in the workforce and encourage a return to the domestic sphere. The provision of one type of program or the other would not increase women's choices, nor would it challenge assumptions about women's work, but would simply shift their burden of responsibility from one sphere to another. It is the combination of these two supports that can assist women and men to balance their responsibilities in the labour market and the domestic sphere, and contribute to the pursuit of gender equality. ${ }^{2}$ Women have fought for a reconceptualization of their identity as caregivers and for a more egalitarian division of labour, as well as for targeted services; the equality frame during this period can be identified as a 'woman's perspective' frame.

Feminism of this brand influenced the EU's understanding of gender equality but it was in particular the equality machinery of the EU which facilitated a shift in the EU's approach to gender equality in the 1980s, from a strategy of inclusion to a strategy of reversal. A European feminist network had begun to emerge by the 1980s and as women began to work at the EC and European Parliament (EP), the EU increasingly adopted positive action measures and reconciliation discourse. The 1974 SAP was the first European document to allude to childcare as a means to enable mothers to reconcile family responsibilities with working life, marking the EU's entry into the realm of childcare policies. Subsequently, many European texts focused on the connection between childcare and gender equality. The 1989 Community Charter of the Fundamental Social Rights of Workers contained equality of treatment provisions, not simply in paid employment but also in education, social protection, and in reconciling work and family

\footnotetext{
${ }^{2}$ However, there is disagreement within the feminist discipline surrounding reconciliation discourse, as it is associated with the meaning of motherhood. For some feminists, the family was seen as an oppressive institution and insofar as motherhood was the means in which women were subordinated, it was also rejected (Randall 1996: 497). One of the consequences of this rejection of motherhood was a reluctance to engage with the issue of childcare for fear of perpetuating patriarchy through association. There was also disagreement as to the real value of paid work.
} 
obligations. It included a chapter devoted to equal treatment for men and women as a social objective (Commission of the European Communities 1990a: 17). A series of Action Programmes focused on the need to develop public services such as childcare and established pilot projects and networks of experts and women's rights advocates (Pollack and Hafner-Burton 2000: 433). Jacques Delors, EC President from 1985 - 1995, was an instrumental player in facilitating Europe's expanding role in social citizenship. The Delors Commission sought to mobilize political support for new EC initiatives in a variety of areas from interest groups and social movements and, in an effort to achieve this, created bodies of experts to establish strong connections with these communities (Ross 2001: 197).

The European Commission Childcare Network was established in 1986 by the Women's Bureau to develop childcare policy. The Childcare Network was given a broad mandate and left relatively unconstrained by the Delors Commission to promote a feminist agenda (Ross 2001: 197). Peter Moss, coordinator from 1986 - 1996, understood childcare issues as an essential component to addressing unequal gender roles in the domestic sphere and adopted a 'woman's perspective’ policy frame. If male and female relationships were equal in the home, then shifts in labour market relationships would subsequently follow (Ross 2001: 187). The Childcare Network became a significant actor in disseminating information about gender equality to member states and conducting advocacy work alongside feminists and was supported by the Equal Opportunities Unit. During the span of its existence (1986 - 1996), it produced 31 reports, created an extensive database of information and stimulated the informal policy process (Randall 2000: 355). In 1990, the Childcare Network explicitly articulated the need for greater involvement of men in the care of children:

Childcare is a "men's issue" as much as a "women's issue." No formula can be applied uniformly in all families-how responsibilities are shared may vary between families and, within the same family, may vary over time with one parent doing more at one stage and less at another. Having acknowledged this, there is still plenty of scope, and an urgent need, for greater involvement by men in childcare (particularly in families but also as workers in services) and for policies to encourage and support this process. (European Commission Childcare Network, 1990, p. 3)

The advocacy work of the Childcare Network was critical to the eventual adoption of the Recommendation on Childcare in 1992. The Childcare Network had fought for the introduction of binding measures on childcare through the adoption of a framework Directive; while it was 
successful in propelling this onto the EC policy agenda, it was then presented to the Council of Ministers as a Recommendation rather than a Directive. A Directive on this issue, which had significant costs to the state and risked being perceived as an encroachment into the realm of the family, was not likely to pass and so the decision was made to instead pursue a non-binding, “soft law” Recommendation (Hoskyns 1996: 156). The EC employed strategical framing and presented the proposal for a Recommendation as a means to achieve both gender equality between men and women and economic growth (Bleijenbergh et al. 2006: 323). The Council of Ministers then shifted the justification of the Recommendation away from substantive equality for women to arguments for economic growth and a more traditional understanding of formal equality in the labour market (Bleijenbergh et al. 2006: 324). This made the document acceptable to all member states, including the UK. While there had been concern that Britain would exercise its veto right and block the Recommendation, Prime Minister Tony Blair supported childcare services from an economic frame in order to encourage employment growth (Bleijenbergh et al. 2006: 327). Thus, the Recommendation on Childcare was adopted by the Council of Ministers in 1992.

The final text of the Recommendation embraced a broad definition of childcare and identified four key areas where state measures were needed: childcare services, parental leave for employed parents, family-friendly policies at the workplace, and measures to promote the increased participation by men in caring responsibilities (Lewis 2006: 428). Significantly, this was the first Commission document to target male behaviour (Hoskyns 1996: 157). The Recommendation illustrated multiple understandings of reconciliation throughout the document and employed several policy frames. A ‘woman’s perspective’ frame was employed to argue for an equal division of labour within the family and arguments about children's well-being were also taken up, but the majority of the Recommendation viewed provision of childcare services as advantageous to the pursuit of other policy goals, such as increasing mobility of the European labour market and economic growth (Council of European Communities 1992: 1). The Recommendation's conflicting use of reconciliation language highlights the various actors involved in its creation: the Childcare Network had established reconciliation as meaning "the renegotiation of gender roles beyond the labour market and within the family," but the Commission was tied to more standard arguments as it was mandated to legitimate its actions through Article 119 of the Treaty of Rome. The constraints of the Commission and the latitude 
of the Childcare Network, in addition to the effects of strategical framing practices, had led to a combination of policy frames throughout the document (Ross 2001: 194). The Recommendation was significant as it was the first time that European social policy had extended beyond paid employment into the realm of unpaid as well as paid care (Bleijenbergh et al. 2006: 316). Nevertheless, its impact was limited among member states as its soft law status prevented judicial enforcement and many member states already had childcare arrangements established (Bleijenbergh and Roggeband 2007: 451).

After the Delors' presidency came to an end in 1995, there was a backlash across Europe in reaction to the activism of the Commission and member states became more protective over what they saw as incursions into state sovereignty. The Childcare Network was dissolved in 1996 and no equivalent organization was established in its place. Subsequent Commission activity was more conservative and restrained, and it shifted away from a regulatory function to one more concerned with coordination and monitoring (Ross 2001: 206). The Santer Commission, which followed the presidency of Jacques Delors, focused almost exclusively on mass unemployment, low growth, and the creation of the Economic and Monetary Union (EMU) in order to restore economic competitiveness to European countries. In 1995 the budget of the Equal Opportunities Unit was cut in half, followed closely by the removal of the director of the Unit, Agnès Hubert. While nine gender expert groups in various policy areas had been struck under the Third Action Programme, seven of them were dismantled and discontinued (Stratigaki 2005: 173). This was done against the backdrop of the Single European Act and the unanimous decision by member state governments to improve competitiveness and complete market liberalization (Hoskyns 1996: 141). These decisions signaled a fundamental change in emphasis of the EU, establishing market liberalization and deregulation as the new orthodoxy of the EU. Childcare continued to be an area of interest to the Commission, but subsequent commitments were more explicit in their understanding of childcare through an economic frame.

While the First and Second Medium-Term Community Action Programmes used a 'woman's perspective' frame to interpret reconciliation, the meaning of the term began to shift in the Third Community Action Programme (1991-1995). Reconciliation policies were delineated as a way to "reduce barriers to women's access to and participation in employment" (Commission of the European Communities 1990: 4). The new Community Initiative NOW (New Opportunities for Women) was introduced under this Programme as a means to encourage 
women's participation in the labour market, stating that insufficient childcare services constituted a barrier to women's integration into the labour market. This reflected the EU's economic, and specifically employment, concerns. Although the Third and Fourth Medium-Term Community Action Programmes were framed as involving both men and women as opposed to targeting women only (as in the First and Second Community Action Programmes), the measures emerging from these Programmes addressed women exclusively (Stratigaki 2004: 43). The understanding was that it was women who would do the reconciling, which represented a shift away from understanding gender equality as a rebalancing of roles in the family sphere, and back towards a strategy of inclusion in the labour market.

Parental leave programs are perceived to be a crucial component of state services by feminists espousing a strategy of reversal and a 'woman's perspective,' as it is the combination of parental leave and childcare services which will provide women with greater flexibility and freedom in shaping their lives. Parental leave enjoyed only a brief presence on the EC agenda, appearing at a time when fertility rates were declining in many European states and populations were aging. This raised concerns about a diminishing labour supply in years to come, prompting the EC to focus on policies which would encourage a greater reproduction of labour in order to sustain the economy (Duncan 2002: 310). A 1994 White Paper proposed a series of measures that would reduce the risks of economic convergence for member states. One of these was parental leave, and the White Paper connected it to working flexibility and the reconciliation of family and work life, as well as the "individualization of taxation and social security systems" (European Commission 1994b: 150). A Directive on Parental Leave was adopted in 1996, more than a decade after it had first been proposed (and eventually dropped because it was considered too prescriptive in its intention to change men's behaviour through non-transferable entitlements). The Commission's DG V introduced the Directive through reconciliation discourse and employed strategical framing to justify its existence through arguments for gender equality as well as economic growth. It was argued that a changing job market required more female workers; measures assisting workers to reconcile their working life with their family life would allow women to become more active in the labour market (Ross 2001: 200).

The final text of the Parental Leave Directive employed various policy frames throughout the document. First, a 'woman’s perspective’ frame was used: parental leave was recognized as an individual and non-transferable right for both women and men. There was also a provision for 
emergency leave in the event of family illness or a medical accident. There were indications of an economic frame as the majority of details, including pay and social security matters, were left to be negotiated by each member state. No minimum remuneration requirements were specified, which suggested that men were much less likely to take it (as concluded by Bruning and Platenga in their 1999 study of eight European countries). Parental leave entitlement was only to be granted once a worker completed a certain period of work, and allowed employers to postpone the parental leave for "justifiable reasons related to the operation of the undertaking" (Council of the European Communities 1996: 5). The text of the Directive suggests that there was a greater concern with increasing flexibility in the market place than with gender equality. By the time the Directive was implemented, its stipulations were so minimal that it marked an improvement for only a few member states: Belgium, Luxembourg, and Ireland (the UK had opted out of the Agreement on Social Policy and so was not obliged to abide by these stipulations). The 1997 Treaty of Amsterdam also included provisions pertaining to parental leave, specifying that all member states must offer three months of unpaid leave to both men and women through a nontransferable credit until the child's eighth birthday. However, attention to parental leave was short-lived and the Commission quickly resumed its primary focus on the provision of childcare programs, which were of greater benefit within an economic frame.

Despite the colder political climate in the later years of the 1990s, the EWL mounted an effective campaign to have broader equality measures included in the Amsterdam Treaty. The EWL adopted a strategy premised on the understanding that they would need to provide a perspective of expertise in order to gain legitimacy, and they set up meetings with member states to explain the significance of the Treaty, as well to garner support for extending gender equality provisions within it. The EWL positioned itself as an ally of the Commission by arguing on behalf of the EC that the Treaty was worth adopting in its own right; it was subsequently granted the opportunity to comment on treaty drafts and articulate its demands in position papers (Helfferich and Kolb 2001: 151). It helped to disseminate a 'gender' policy frame and influenced the adoption of GM measures. Pressure from Sweden, Finland and Denmark also had an impact upon the equality provisions of the Amsterdam Treaty and to the adoption of GM as a formal strategy of the EC. Upon joining the EU in 1994, the governments of Sweden and Finland were under considerable pressure to prove to their constituencies that the EU was women-friendly, as a series of referenda before accession had revealed that women in these countries were doubtful 
of the EU's receptiveness of gender equality. Swedish women had voted against joining the EU, female constituents in Denmark voted against the Maastricht Treaty because of its limited consideration of gender equality, and only by a slight majority had women in Finland voted in favour of joining (Duncan 2002: 309). The final Amsterdam Treaty included Article 13, which allowed the EU to challenge discrimination practices, and Article 141 which extended Article 119 from the Treaty of Rome, stipulating that women and men should receive equal pay for work of equal value (Zippel 2004: 77). The most far-reaching provisions of the Treaty were Articles 2 and 3, which made gender equality between women and men a central objective of all EU activities.

The meaning of reconciliation continued to shift towards a more purely economic policy frame. Reconciliation was identified as an integral part of the European Employment Strategy (EES) process in order to promote female labour market participation (Lewis 2006: 429). Childcare had regularly been identified as a factor in strengthening the Equal Opportunities Pillar in the National Action Plans on employment since 1998. The 2000 Lisbon Summit suggested setting national targets with respect to childcare based on best practice which were accompanied by commitments to full employment and specific targets to increase women's employment. This effectively narrowed the rationale for providing childcare services to reaching employment targets and limited the understanding of childcare to formal provision rather than parental leave (Lewis 2006: 430). This was followed by the Barcelona European Council in 2002 which agreed on targets for the provision of non-parental childcare facilities in order to facilitate higher employment rates for both women and men. During this period, there were few indications of concern with gender equality as a goal, as the 'woman's perspective' frame slipped off the policy agenda and childcare came to be seen as a means to achieve full employment rates within an economic frame.

A further indication of the gradual shifts in meaning of equality concepts was the fact that reconciliation discourse began to be employed outside of gender equality and social policy documents. The 1994 White Paper “Growth, Competitiveness, Employment” referred to the need for increased flexibility in the labour market, to which parental leave could positively contribute, and referred to reconciliation of work and family life in order to reduce indirect labour costs (European Commission 1994a: 150). Reconciliation became increasingly detached from equality discourse and instead was tied to new commitments of flexibility and security in the workplace; 
in other cases it was used to address falling birth rates. During the latter half of the 1990s, reconciliation began to be seen as the ultimate compromise able to simultaneously address demographic concerns, economic concerns, and gender equality, and it came to be included in all major EU policies related to organization of work or employment (Stratigaki 2004: 46). For instance, the 1996 Green Paper "Living and Working in the Information Society: People First" discussed the use of technology in improving the balance between work and family life (European Commission 1996: 25). The meaning of reconciliation had shifted dramatically since its inception into EU discourse, from a concept able to highlight the significance of care programs in the pursuit of gender equality, to one which legitimated economic aims. Ultimately, gender equality goals had been co-opted and subsumed into an economic frame.

In this phase of EU policy formulation, many of the initiatives on gender equality were catalyzed by lobbying activities of the feminist movement, spearheaded by institutions of the equality machinery of the EU. The Childcare Network was instrumental in disseminating knowledge about the need for childcare services in pursuit of gender equality between women and men, and portions of the final text of the Recommendation reflected this policy frame. The Parental Leave Directive was introduced by the DG V through a 'woman's perspective' frame, and the EWL spearheaded a large lobbying campaign in order to incorporate stronger equality legislation within the Treaty of Amsterdam. Strategical framing was employed by each of these actors to varying degrees, in an attempt to increase the likelihood of adoption into the EU's policy agenda. The final texts illustrated shifts in meaning away from the initial 'woman's perspective’ policy frame. Over time, EU commitments to gender equality articulated through reconciliation discourse became increasingly weaker, and equality activity was recast within a broader economic frame which coincided with a liberal understanding of gender equality 'equal treatment' in the labour market.

Despite this preoccupation with economic priorities, gender equality became even more entrenched within the EU. In 1996, the Commission issued a Communication which committed to examining all EU policies with a gendered lens. This marked the formal introduction of GM into EU politics, which has since become the major focus of EU gender equality efforts. 


\section{Gender Mainstreaming}

The third and most recent phase of the EC's approach to gender equality has been Gender Mainstreaming (GM). GM is grounded in a strategy of displacement and poststructuralist feminism. Poststructural feminists view the state as a discursive process rather than merely as institutions; the state is not seen to be inherently patriarchal in nature but was historically constructed as patriarchal. The state, therefore, is at the centre of a reverberating set of power relations and political processes which both construct and contest patriarchy (Kantola 2006: 12). Poststructural feminists see the state as a terrain of struggle which can be both a positive and a negative resource but they focus on displacing patriarchal relations and deconstructing those discursive regimes which ascribe gender roles. Such discursive processes are conceptualized as the location of both the problem and the solution of gender inequality (Kantola 2006: 13). GM claims to address and redress gendered systems; as such, it has attracted a great deal of attention from academics as it contends that it can lead to a world beyond gender.

The incorporation of GM into the EU equality agenda in 1996 resulted in a much broader purview for equality policies. Mainstreaming builds upon previous understandings of gender equality and inequality. GM has been called a "three-legged equality stool" in that it is must work with both 'legs' of equal treatment and positive action measures in order to be successful (Booth and Bennett 2002: 434). It focuses on issues of gender rather than on women, widening its view of what contributes to gender inequality. Gender issues are relevant within all policy areas and GM brings this to the fore, expanding responsibility for who, and what, contributes to inequality. GM demands the redefinition of policy goals to incorporate the promotion of gender equality as an overarching policy objective, and calls for the re-examination and reformation of the policy process to incorporate a gendered perspective. It refers to both a strategy to achieve equality as well as a process, and prescribes a specific set of tools and methods with which to implement the strategy (Booth and Bennett 2002: 442). The equality frame during this period can be identified as a 'gender' frame.

While GM is widely perceived to be a new strategy of gender equality, it is worth noting that the three strategies of inclusion, reversal, and displacement can be constituted within mainstreaming practices themselves (Squires 2005: 370). Mainstreaming can be understood to mean different things, and the ways in which mainstreaming practices are applied impact 
whether it fits within a strategy of inclusion or achieves its transformative potential. Strategies of inclusion, or integrationist approaches, address gender issues from within existing policy paradigms, whereas strategies of reversal imply the transformation of policy structures through increasing women’s participation as decision-makers (Jahan 1996: 829). It is widely accepted that mainstreaming must employ a transformative approach in order to adequately address fundamental issues of gender inequality, as both a strategy of inclusion and reversal fail to challenge dominant gendered norms (Beveridge and Nott 2002: 300).

In February 1996, the Commission officially adopted GM as a strategy. GM was defined as:

Mobilizing all general policies and measures specifically for the purpose of achieving equality by actively and openly taking into account at the planning stage their possible effects on the respective situations of women and men (gender perspective). (emphasis in the original)

(Commission of the European Communities 1996a: 2).

The Communication stressed the importance of using a gendered lens to examine various policy areas, but failed to provide any overarching goal or objective, an expectation of outcomes or timeline, or a strategy for the implementation of GM. It made no reference to the connection between GM and women's participation in decision-making, nor did it suggest how to allocate human resources or funds in the implementation of GM (Stratigaki 2005: 175). It was drafted by two male officials, neither of whom had any prior experience dealing with gender equality. They had rejected requests from the Equal Opportunities Unit to provide input, stating that this would adopt a "woman's ghetto" approach and was therefore not appropriate for GM, which could be designed by anybody (Stratigaki 2005: 175). Arguably, this contributed to a confusing definition of GM.

The first progress report on the follow-up to the Communication was adopted in 1998, this time with greater input from the Equal Opportunities Unit and other women. The progress report included a new definition of GM which was much more comprehensive:

The systematic integration of the respective situations, priorities and needs of women and men in all policies and with a view to promoting equality between women and men and mobilizing all general policies and measures specifically for the purpose of achieving equality by actively and openly taking into account, at the planning stage, their effects on the respective situation of women and men in implementation, monitoring and evaluation. (Commission of the European Communities 1998: 2). 
This report outlined the need for a "dual strategy" approach (combining GM with positive action measures). Such a strategy was officially launched within the EC and it was particularly due to the individual efforts of female commissioners that it was effectively implemented using a 'gender' policy frame. A strategy and action plan on 'Women in Science', the DAPHNE initiative combating violence against women, and the incorporation of a GM strategy into the EU Structural Funds policy all employed a dual track strategy effectively (Stratigaki 2005: 179). The influence of individual female politicians was further felt when Commissioner Anna Diamantopoulou and Barbara Helfferich, a member of her cabinet, were successful in their fight to continue the mid-term action programmes, which had been threatened to be terminated due to arguments that GM precluded the need for other positive action measures. The Framework Strategy for Gender Equality (2001-2005) was adopted and the action programmes continued, marking an unmistakable success for gender equality issues. While these women were unable to transform dominant norms across the EU, their experience illustrated that with political will, a 'gender' frame could be promoted within the EU political agenda.

A “dual strategy" approach is essential, as GM could otherwise be used as a justification for diluting gender expertise and eliminating specific positive action approaches altogether. Maria Stratigaki notes that the annual Commission report, "Employment in Europe” contained a chapter on women's employment from 1989 until 1993, and in 1994 it examined all chapters through a gendered lens; by 1995, both these approaches had been terminated, stating that the use of GM in the drafting of the policy meant that these measures were no longer necessary (Stratigaki 2005: 176). In the field of education, budget allocations for equality projects were discontinued with the argument that GM had already been employed. The NOW Community Initiative, an important source of financing and support for women in vocational training and enterprise creation, lost its funding as the issue was mainstreamed within employment policy (Woodward 2008: 76). Within these areas, a 'gender' frame did not resonate with the dominant frame and was therefore rejected. While the Fourth Medium-Term Community Action Programme for Equal Opportunities Between Women and Men featured mainstreaming as its most central element, this altered the shape of the projects which received funding under this programme, and small enterprises initiated by women's organizations were set aside as larger-scale projects proposed by organizations such as the social partners received funding instead. These were significant losses for feminists and for gender equality issues. 
Equality goals continued to face difficulties under GM as it had under previous EU policy approaches, and so feminists used strategical framing practices in order to create a resonance between equality goals and other policy priorities. While strategical framing contains inherent dangers when employed with any policy goal, it is particularly dangerous when used to justify GM. In order to be an effective strategy, GM needs to retain its ability to challenge gendered policy goals and processes. Strategical framing of GM increases the likelihood that it will turn into an integrationist approach, subsuming gender into existing policy frames rather than rethinking the fundamental aims of the EU from an equality perspective. This likelihood is increased even further by the fact that GM lacks specific objectives on reducing gender inequalities and is fairly vague, which allows it to be easily reshaped and relocated within other policy frames.

The EU's Structural Funds were the first test case for the Commission's new GM mandate. The Commission created a set of draft Regulations for 2000-2006, which mainstreamed gender across every area of structural operations. The proposed Regulations presented ten articles containing specific requirements for effective and successful incorporation of a gendered perspective at every stage in the policy process. Strategical framing was consistently used throughout the drafting and negotiation process, as GM was framed not only as a means to achieve gender equality, but also as an issue of social justice and economic growth (Pollack and Hafner-Burton 2000: 441). This stretching of the gender equality goal placed it alongside other political goals to resonate with other policy frames. There was little resistance and the gender provisions of the new Regulations were adopted by the Council of Ministers with very few changes, marking a success for GM (Pollack and Hafner-Burton 2000: 442). However, one consequence of this was greater attention accorded to an 'equal treatment' perspective instead of a 'gender' perspective, and the main objective of the Structural Funds with regard to gender equality was stated as being increased female in the labour market (Braithwaite 2000: 11). Despite requirements that a gender perspective be applied to all areas of the Structural Funds, this has not been the case as "hard" areas (such as transport and energy) have been insulated from this and only "soft” areas (such as training and agrotourism) have been subject to a gender perspective (Braithwaite 2000: 7). Recent studies have shown that there are very few specific equality objectives and actions within Structural Fund documents, and only rarely is a 'gender' perspective used (EWL 2002: 1). This demonstrates a significant shift away from the initial 
understanding of GM and the experience of GM within the Structural Funds has led to the conclusion that the "European Commission is stronger on policy formulation than on developing accompanying arguments, procedures and instruments for translating policy into practice” (Braithwaite 2000: 7). In another study, Mark Pollack and Emilie Hafner-Burton examined five issue-areas of the EU and found that mainstreaming advocates employed strategical framing within all five areas. They further argued that this act of strategical framing had a direct impact in shaping the EU's approach to GM as an integrationist strategy rather than transformative (2000: 452).

The Structural Funds case illustrates many of the difficulties GM faces within the EU. There have been persistent criticisms that EU mainstreaming efforts have not effectively been incorporated with many of the core areas of EU policy and spending, such as transport, competition, environment, foreign policy, and agriculture (Woodward 2008: 75). Resistance to GM has been fairly common across departments and there has been significant variation in approaches to mainstreaming across divisions of the Commission. The incorporation of GM is made more difficult by its use of predominantly "soft” policy instruments, such as benchmarking and guidelines, which are generally voluntary. The use of soft policy measures has limited the scope of GM within the EC and results have been reported to be uneven, fragile and vulnerable to setbacks or reversals (Rubery 2002: 510). Such tepid outcomes of GM are not accidental. Various policy areas employing a policy frame which is antagonistic to equality aims have rejected a 'gender' perspective; while this has been mitigated by strategical framing practices, the act of strategical framing has encouraged GM to adopt an integrationist approach and relinquish its transformative potential in order to gain a place on the policy agenda. The degree to which a particular policy area has had experience dealing with gender policies, prior to the introduction of Mainstreaming, has been proven to be inversely correlated to the extent of compromise required by the very tools which are intended to challenge and transform gender norms (Woodward 2008: 67). A sympathetic policy frame is likely to find a resonance with GM and a 'gender' policy frame, whereas a frame that is unfamiliar with gender issues will require a greater degree of strategical framing. It is questionable whether the short-term successes of strategical framing are worth the constraining effects felt in the long-term, for without its potential to transform dominant norms, GM becomes a toothless policy approach which is likely to be used to legitimate economic goals rather than contribute to the pursuit of equality. 
Widespread confusion about what GM strategies involve have led to concerns about its vulnerability to being co-opted and used against feminist goals, or reduced to merely a "tick box.” In the absence of firm and understandable definitions of gender equality or mainstreaming, how can such goals be realized and strategies be operationalized? While any definition of gender equality must remain open and flexible, ambiguous references allow the definition to become a “chameleon, changing colour with every social and political context” (Verloo 2005: 355). Conceptualization of the goal itself, as well as an idea of how to operationalize the goal, is essential in order to realize GM's transformative potential. Ute Behning and Serrano Pascual (2001) examined the impact of GM in national practices of employment and found that understandings of GM varied widely, from equal participation to affirmative action, or reform of government. They concluded, however, that most GM policies were simply a continuation of previous equality policies (Behning and Pascual 2001).

Twelve years after its original launch, GM has failed to radically transform policy processes within the EU. It has had limited reach in policy-areas and continues to be kept outside the debate with regard to core EU macroeconomic policies. In the areas where it has been most successful, it has been criticized as being a mere continuation of previous gender policies rather than the start of a new approach. In other areas, it has been employed as an excuse to dismantle women's machinery and eliminate positive action programs. The resistance to GM within EU institutions demonstrates continued challenges to the adoption of a gender equality frame. Strategical framing of GM has been shown to be ineffective, merely diluting the meaning of GM concepts which are absorbed into other policy frames, rather than promoting a strong gender equality frame. Evidence of a declining focus on gender issues, coupled with the dismantling of equality programs and diminishing attention to promoting the equal sharing of unpaid care work between men and women, suggests that GM has done little substantively to advance gender equality. The institutionalization of GM within EU policy processes provides the transformative potential for policies to become more inclusive and sensitive to gender and diversity; however, achieving this potential will only occur through a consideration of the power relationships involved in the politics of framing. Gender equality must be pursued as an essential goal in its own right within a strategy of mainstreaming; strategical framing will downplay the importance of gender equality and privilege other policy priorities, thereby relegating GM to an integrationist approach. As long as equality is seen as an instrument to achieve broader 
employment and economic goals, GM will be unable to achieve its transformative potential in leading us to a world beyond gender.

\section{Conclusion}

The EU has presented a favourable opportunity structure for feminist groups, allowing multiple points of access to the policy process and embedding various allies within its institutional structure. This equality machinery has been instrumental in the development of equality policies (Ross 2001: 203). However, despite initial correlations with feminist understandings of equality, EU policy has eventually shifted back towards economic concerns within each time period. Such shifts have been gradual and uneven, but a historical analysis reveals that the EU has maintained a liberal approach to equality and has limited meanings of equality to 'equal treatment' in the labour market. Increasing labour market participation has simultaneously been a goal of its dominant policy frame of economic growth. Despite an extensive gender regime, equality legislation has faced persistent challenges. Conflicts between policy frames involve struggles over power; backed by unequal resources, advocates of equality goals have employed strategical framing in order to overcome this disadvantage. While strategical framing has been relatively successful in providing equality goals an initial place on the policy agenda, over time this opening has narrowed as equality concepts have been watered down and subsumed within the dominant frame. Strategical framing can therefore be seen as a combination of enabling and constraining effects and must be employed carefully, with great attention to how power is at work within such practices. This strategy is especially dangerous when employed to create linkages between GM and other policy frames, for GM's greatest strength is its ability to challenge dominant norms. Strategical framing weakens this capacity and increases the likelihood that it will be integrated into the dominant policy frame and used to legitimate economic goals. While the enabling elements of strategical framing have been useful for equality goals, it has not yet proven to be effective at providing equality issues with a sustainable position on the policy agenda. Feminists must rely upon deeper analyses of how power frames EU policies and discourse, using this knowledge to explore how to shift the 
Review of European and Russian Affairs vol. 5 issue 1/2009 (C) RERA 2009 all rights reserved

balance of strategical framing effects in their favour and how to sustain attention to equality goals over longer periods of time. 


\section{Bibliography}

Bacchi, Carol Lee. 1999. Women, Policy and Politics: The Construction of Policy Problems. London: Sage Publications.

Behning, Ute and Amparo Serrano Pascual. 2001. "Rethinking the Gender Contract? Gender Mainstreaming in the European Employment Strategy.” In European Trade Union Yearbook 2000, ed. Emilio Gabaglio and Reiner Hoffman. Brussels: ETUI.

Beveridge, Fiona and Sue Nott. 2002. "Mainstreaming: A Case for Optimism and Cynicism” Feminist Legal Studies 10(3-4): 299-311.

Bleijenbergh, Inge, Jet Bussemaker, Jeanne de Bruijn. 2006. "Trading Well-Being for Economic Efficiency: The 1990 Shift in EU Childcare Policies.” Marriage and Family Review 39(3/4): 315-336.

Bleijenbergh, Inge and Conny Roggeband. 2007. "Equality Machineries Matter: The Impact of Women’s Political Pressure on European Social-Care Policies.” Social Politics 14(4): 437459.

Braithwaite, Mary. 1999. "Mainstreaming Equal Opportunities in the Structural Funds: how regions in Germany, France and the United Kingdom are putting into practice the new approach. Final Report of the survey of current practice and findings of the seminar at Gelsenkirchen, January 21-22 1999.” European Commission, DG Regional Policy and Cohesion.

---. 2000. "Mainstreaming Gender in the European Structural Funds.” Mainstreaming Gender in European Public Policy Workshop, University of Wisconsin-Madison 15 October 2000. $<$ http://eucenter.wisc.edu/Conferences/Gender/braith.htm>.

Cain, Patricia A. 1989. "Feminism and the Limits of Equality.” Georgia Law Review 24: 803-848.

Commission of the European Communities. 1981. "A New Community Action Programme on the Promotion of Equal Opportunities for Women 1982-85.” Commission Communication to the Council. COM (81) 758 final, 9 December 1981.

---. 1986. "Second Medium-Term Community Programme on Equal Opportunities for Women (1986-1990).” COM (85) 81 final, 19 December 1985.

---. 1990. "Equal Opportunities for Women and Men. Third Medium-Term Community Action Programme 1991-1995.” COM (90) 449 final, 6 November 1990.

---. 1990a. Community Charter of the Fundamental Social Rights of the Worker. Luxembourg: Office for Official Publications of the European Communities (OOPEC).

---. 1996. "Fourth Medium-Term Community Action Programme on Equal Opportunities for Women and Men 1996-2000.” COM (95) 593 final, 22 December 1995.

---. 1996a. Communication on Incorporating Equal Opportunities for Women and Men into all Community Policies and Activities. COM (96) 67 final, 21 February 1996.

---. 1998. Progress Report from the Commission on the Follow-Up of the Comunication: Incorporating Equal Opportunities for Women and Men into all Community Policies and Activities. COM (98) 122 final, 4 March 1998.

Connell, R.W. 1994. “The State, Gender and Sexual Politics: Theory and Appraisal.” In Power/Gender: Social Relations in Theory and Practice, ed. H. Lorraine Radtke and Henderikus J. Stam. London: Sage Publications. 136-173.

Council of Europe, Committee of Ministers. 1998. Recommendation No. R(98) 14 of the Committee of Ministers to Member States on Gender Mainstreaming. Adopted by the Committee of Ministers on 7 October 1998 at the $643^{\text {rd }}$ meeting of the Ministers' Deputies.

Council of the European Communities. 1992. "Council Recommendation of 31.3.92 on Child Care (92/241/EEC).” OJ L 123/8 May 1992. 
---. 1996. “Council Directive 96/34/EC of 3 June 1996 on the Framework Agreement on Parental Leave Concluded by UNICE, CEEP and the ETUC.” OJ L 145/19 June 1996.

Duncan, Simon. 1996. "Obstacles to a Successful Equal Opportunities Policy in the European Union.” European Journal of Women's Studies 3(4): 399-422.

---. 2002. "Policy Discourses on 'Reconciling Work and Life' in the EU.” Social Policy \& Society 1(4): 304-314.

European Commission. 1994a. Growth, Competitiveness, Employment: The Challenges and Ways Forward into the $21^{\text {st }}$ Century. White Paper. Luxembourg: OOPEC.

---. 1994b. Social Policy - A Way Forward for the Union. White Paper. COM(94) 333, final of 27 July 1994. Luxembourg: OOPEC.

---. 1996. "Living and Working in the Information Society: People First.” COM(96) 389 final, 24 July 1996. Green Paper. Bulletin of the European Union Supplement 3/96. Luxembourg: OOPEC.

---. 2008. Gender Mainstreaming of Employment Policies: A Comparative Review of thirty European countries. Luxembourg: OOPEC.

European Commission Childcare Network. 1990. Childcare in the European Community 1985-1990. Brussels, Belgium: Commission of the European Communities.

European Women’s Lobby. 2002. “Gender Mainstreaming in the Structural Funds: Establishing Gender Justice in the Distribution of Financial Resources.” Brussels: EWL. $<$ http://www.womenlobby.org $>$.

Fraser, Nancy. 1997. Justice Interruptus. New York: Routledge.

Hantrais, Linda (ed.). 2000. Gendered Policies in Europe: Reconciling Employment and Family Life. London: Macmillan.

Hoskyns, Catherine. 1996. Integrating Gender: Women, Law and Politics in the European Union. New York: Verso.

Jahan, Rounaq. 1996. “The Elusive Agenda: Mainstreaming Women in Development.” Pakistan Development Review 35(4): 825-834.

Jenson, Jane and Mariette Sineau. 2001. Who Cares? Women's Work, Childcare, and Welfare State Redesign. Toronto: University of Toronto Press.

Kantola, Johanna. 2006. Feminists Theorize the State. New York: Palgrave MacMillan.

Lewis, Jane. 2006. "Work/Family Reconciliation, Equal Opportunities and Social Policies: The Interpretation of Policy Trajectories at the EU Level and the Meaning of Gender Equality.” Journal of European Public Policy 13(3): 420-437.

Lombardo, Emanuela and Petra Meier. 2006. “Gender Mainstreaming in the EU: Incorporating a Feminist Reading?” European Journal of Women's Studies 13(2): 151-166.

Mackinnon, Catharine. 1989. Towards a Feminist Theory of the State. London: Harvard University Press.

Mahon, Rianne. 2002. “Child Care: Toward What Kind of 'Social Europe’?” Social Politics 9(3): 343-366.

Mazey, Sonia. 1998. “The European Union and Women’s Rights: From the Europeanization of National Agendas to the Nationalization of a European Agenda?” Journal of European Public Policy 5(1): 131-152.

---. 2000. “Introduction: Integrating Gender - Intellectual and ‘Real World’ Mainstreaming.” Journal of European Public Policy 7(3 Special Issue): 333-345.

---. 2002. “Gender Mainstreaming Strategies in the EU: Delivering on an Agenda?” Feminist Legal Studies 10(3-4): 227-240.

O’Connor, Julia S. 2005. “Employment-Anchored Social Policy, Gender Equality and the Open Method of Coordination in the European Union.” European Societies 7(1): 27-52. 
Peterson, Elin. 2007. “The Invisible Carers: Framing Domestic Work(ers) in Gender Equality Policies in Spain.” European Journal of Women's Studies 14(3): 265-280.

Pollack, M.A., and E. Hafner-Burton. 2000. "Mainstreaming Gender in the European Union.” Journal of European Public Policy 7(3 Special Issue): 432-456.

Randall, Vicky. 1996. "Feminism and Child Daycare.” Journal of Social Policy 25(4): 485-505.

---. 2000. "Childcare Policy in the European States: Limits to Convergence.” Journal of European Public Policy 7(3 Special Issue): 346-368.

Rees, Teresa. 1998. Mainstreaming Equality in the European Union: Education, Training and Labour Market Policies. London: Routledge.

Ross, George. 2001. “Europe: An Actor without a Role.” In Who Cares? Women's Work, Childcare, and Welfare State Redesign, ed. Jane Jenson and Mariette Sineau. Toronto: University of Toronto Press. 177-213.

Rubery, Jill. 2002. "Gender Mainstreaming and Gender Equality in the EU: The Impact of the EU Employment Strategy.” Industrial Relations Journal 33(5): 500-522.

Snow, David A. and Robert D. Benford. 1992. "Master frames and cycles of protest” In Frontiers of Social Movement Theory, ed. Aldon D. Morris and Carol McClurg Mueller. New Haven: Yale University Press.

Squires, Judith. 2005. "Is Mainstreaming Transformative? Theorizing Mainstreaming in the Context of Diversity and Deliberation,” Social Politics 12(3): 366-388.

Stratigaki, Maria. 2000. “The European Union and the Equal Opportunities Process” in Gendered Policies in Europe, ed. Linda Hantrais. Great Britain: Macmillan Press Ltd.

---. 2004. "The Cooptation of Gender Concepts in EU Policies: The Case of 'Reconciliation of Work and Family'." Social Politics 11(1): 30-56.

---. 2005. “Gender Mainstreaming vs. Positive Action: An Ongoing Conflict in EU Gender Equality Policy.” European Journal of Women's Studies 12(2): 165-186.

Verloo, Mieke. 2005. "Displacement and Empowerment: Reflections on the Concept and Practice of the Council of Europe Approach to Gender Mainstreaming and Gender Equality.” Social Politics 12(3): 344-365.

Walby, Sylvia. 2004. "The European Union and Gender Equality: Emergent Varieties of Gender Regime.” Social Politics 11(1): 4-29.

Woodward, Alison. 2008. "European Gender Mainstreaming: Promises and Pitfalls of Transformative Policy” Review of Policy Research 20(1): 65-88.

Young, Brigitte. 2000. “Disciplinary Neoliberalism in the European Union and Gender Politics.” New Political Economy 5(1): 77-98.

Zippel, Kathrin. 2004. "Transnational Advocacy Networks and Policy Cycles in the European Union: The Case of Sexual Harassment.”Social Politics 11(1): 57-85). 